\title{
The many hats of a Cold War scientist
}

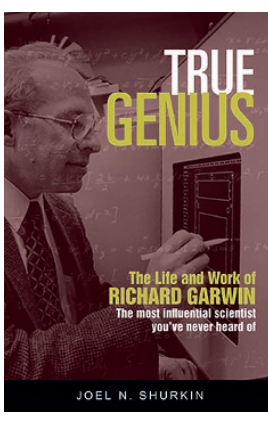

True Genius:

The Life and Work of Richard Garwin

By Joel N. Shurkin

PROMETHEUS: 2017

340 PP. $€ 20$

$\mathrm{R}$ ichard Garwin, as several popular accounts have recently emphasized, is the most influential American scientist that nobody has heard of. The 'nobodies' in this statement are probably not the readers of Nature Physics, but it is true that outside the realms of physics, arms control or defence science, Garwin is an obscure figure. Joel N. Shurkin's True Genius: The Life and Work of Richard Garwin is the first book-length biography of the man who Enrico Fermi reportedly called "the only true genius" he had ever met.

Garwin's obscurity is in some sense remarkable, given both the extent of his interests and influence, and the fact that he has not shied away from making public statements or working with journalists. And recently, at the age of 88 , Garwin received the Presidential Medal of Freedom. What accounts for his obscurity?

In the communities that care about defence science, Garwin's work is legendary. To list it in detail would take, well, a biography. But in short: he was largely responsible for the practical design of the 'Sausage', the world's first experimental hydrogen bomb; he was a long-time member of the President's Science Advisory Committee and a member of the JASON advisory group, providing independent technical advice on a variety of topics; he was involved in the creation of the ill-fated 'electronic barrier' meant to disrupt the Ho Chi Minh trail during the Vietnam War; he contributed analysis for spy satellites, nuclear weapons treaties, nuclear detonation detection, anti-ballistic missile systems, and was an intense and principled critic of the Strategic Defense Initiative in the 1980s.

His reputation is that of innovative technical creativity and near-machine-like mental virtuosity. As a colleague of mine put it to me recently, you can almost trick yourself into thinking you can hear gears whirring as he processes an idea. His manner is slightly robotic, but not cold. One feels pity for people who find themselves on the wrong end of his contempt: there is nothing he likes more than showing the many ways in which someone is wrong. Former Secretary of Defense William Perry characterizes Garwin as "an acquired taste... very smart, and sometimes a little impatient with anyone not as smart as he is." Less flatteringly, Freeman Dyson, a fellow JASON member and scientific consultant to the government, describes Garwin as someone who has "no mercy" for error: "Something wrong is wrong and he would just grind you to the ground for it." Even his good friends seem to agree that if the problem is technical in nature, Garwin will probably come up with an ingenuous solution to it almost instantly, but if the problem is human in nature, beware.

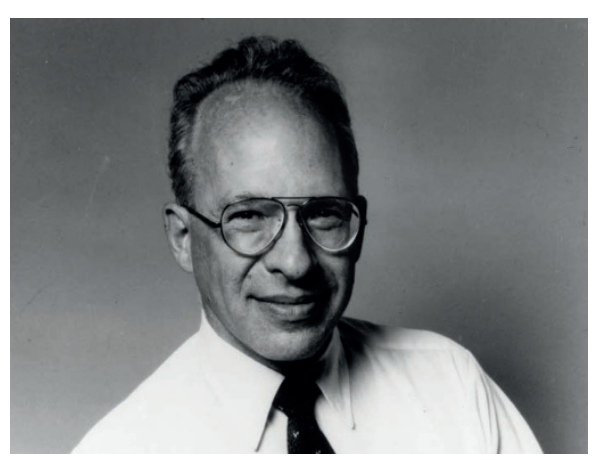

At the same time, however, anyone who has ever reached out to Garwin for information, recollections or quotations knows that he is generous with his time, and always eager to enlighten and assist those who are truly interested in learning the truth (as he sees it). One never gets the sense, talking or listening to Garwin, that he has an axe to grind: he is possessed with a sense of what is true, and he struggles with the fact that the operation of the world is often about factors other than truth.

Garwin was at times a weapons scientist, but not one who ever saw himself as primarily affiliated with a weapons laboratory. He was at times a university scientist, but he preferred not to teach or mentor, and his major contribution to academic science, the Garwin-LedermanWeinrich experiment, while an elegant experimental demonstration of violation of parity, is obscure enough to not even have its own Wikipedia article. He was at times an industrial scientist, working

\section{for IBM Research laboratories for most} of his career, but at the same time, he was never so closely associated with industrial development as were those scientists who spun out huge contributions to the militaryindustrial complex. And he was at times a government advisor, but always as an independent voice, often as a gadfly despite his internal status. Though in many of these things he was exceptional, the sum of them is an apt demonstration of the conundrum of the Cold War, the way it allowed scientists and technologists to cross through multiple domains of society (academia, industry, government) in a way that was both seamless and profitable.

Perhaps this is why Garwin is still so obscure. Much of his work is in this 'blended' mode, with few capstones to hold up as uniquely his own, which popular attention tends to cluster around. His work on the hydrogen bomb was almost completely unknown outside of the classified community until 2001, a casualty of secrecy restrictions (and, perhaps, his own modesty on the topic). His greatest academic scientific achievement is remarkably difficult to explain in lay terms. The main outcome of his JASON work that he is known for (the barrier) was a failure that got him derided as a 'baby killer' (it was never implemented correctly, Garwin says). His opposition to the Strategic Defense Initiative made it into newspapers, but his was one (albeit powerful) voice among many, and while brilliant, he was never the most charismatic spokesman for science. And yet, a persuasive case can be made that a full accounting for a career like Garwin's is more definitive of the role of scientists in the late twentieth century than those of many of his more famous contemporaries.

And therein lies a paradox: Garwin is important, and should be the fodder of many interesting and probing biographies. But he is obscure, and probably not going to attract as much attention as yet another book on Einstein, Feynman or Oppenheimer. Shurkin's book is unfortunately extremely inadequate - frustratingly so - and marked by an unusual number of scientific and historical errors. Garwin's story deserves to be told better than this.

\section{REVIEWED BY ALEX WELLERSTEIN}

Alex Wellerstein is at the College of Arts and Letters at Stevens Institute of Technology, Hoboken,

New Jersey 07030, USA.

e-mail:awellers@stevens.edu. 